\title{
MENENTUKAN PORTOFOLIO OPTIMAL PADA PASAR SAHAM YANG BERGERAK DENGAN MODEL GERAK BROWN GEOMETRI MULTIDIMENSI
}

\author{
Riska Yunita $^{\S 1}$, Komang Dharmawan ${ }^{2}$, Luh Putu Ida Harini ${ }^{3}$ \\ ${ }^{1}$ Jurusan Matematika, Fakultas MIPA - Universitas Udayana [Email: riska.yunita8@ gmail.com] \\ ${ }^{2}$ Jurusan Matematika, Fakultas MIPA - Universitas Udayana [Email: dharmawan.komang@gmail.com] \\ ${ }^{3}$ Jurusan Matematika, Fakultas MIPA - Universitas Udayana [Email: ballidah@gmail.com] \\ ${ }^{\S}$ Corresponding Author
}

\begin{abstract}
Model of stock price movements that follow stochastic process can be formulated in Stochastic Diferential Equation (SDE). The exact solution of SDE model is called Geometric Brownian Motion (GBM) model. Determination the optimal portfolio of three asset that follows Multidimensional GBM model is to be carried out in this research.Multidimensional GBM model represents stock price in the future is affected by three parameter, there are expectation of stock return, risk stock, and correlation between stock return. Therefore, theory of portfolio Markowitz is used on formation of optimal portfolio. Portfolio Markowitz formulates three of same parameter that is calculated on Multidimensional GBM model. The result of this research are optimal portfolio reaches with the proportion of fund are 39,38\% for stock BBCA, 59,82\% for stock ICBP, and 0,80\% for stock INTP. This proportion of fund represents value of parameters that is calculated on modelling stock price.
\end{abstract}

Keywords: stochastic process, Stochastic Differential Stochastic, Geometric Brownian Motion, portfolio Markowitz

\section{PENDAHULUAN}

Pembentukan harga saham dipengaruhi oleh berbagai informasi baik informasi internal perusahaan ataupun informasi tentang keadaan ekonomi global (eksternal). Teori Efficient Market Hypothesis menyatakan bahwa harga saham yang terbentuk merupakan cerminan dari seluruh informasi yang ada (Fama, [2]). Setiap investor akan bereaksi terhadap harga saham berdasarkan informasi yang diterima, sedangkan terdapat banyak investor yang melakukan perdagangan saham pada pasar modal, sehingga peregerakan harga saham tidak dapat diprediksi dan bergerak secara acak.

Pergerakan saham yang demikian menyulitkan investor untuk memprediksi harga saham pada periode mendatang. Oleh karena itu, dibentuk model matematika harga saham yang dirumuskan dalam Persamaan Diferensial
Stokastik (PDS). Penyelesaian suatu PDS dengan menerapkan teori kalkulus stokastik menghasilkan solusi yang disebut dengan model Gerak Brown Geometri (GBG). Terdapat beberapa penelitian terdahulu yang menerapkan teori kalkulus stokastik pada analisis sekuritas di bidang finansial, yaitu Black dan Scholes [1], Nizaruddin [5] ,Noorbaity \& Aisiyah [6], dan Pradhitya [7]. Penelitian di atas melakukan analisis sekuritas pada pasar modal satu dimensi (terdiri atas satu sekuritas). Oleh karena itu, akan dilakukan analisis sekuritas pada pasar saham multidimensi berupa portofolio saham yang bergerak mengikuti model GBG. Analisis sekuritas yang akan dilakukan berupa mengestimasi harga saham pada periode mendatang melalui simulasi saham dan pembentukan portofolio optimal. 
Pada pemodelan matematika dari pergerakan harga saham multidimesni, diasumsikan pergerakan harga dari masingmasing saham dapat dimodelkan sebagai PDS atau dengan kata lain pergerakan harga sahamnya mengikuti model GBG, sehingga model pergerakan harga saham multidimensi dirumuskan dalam suatu PDS Multidimensi. Secara umum model PDS Multidimensi saham dirumuskan sebagai berikut (Kloeden \& Platen, [4]):

$$
d S_{t}^{i}=S_{t}^{i}\left(\mu_{i} d t+\sum_{j=1}^{3} \sigma_{i j} d W_{j}\right)
$$

untuk $i=1,2, \ldots, n$

Penyelesaian eksak model PDS Multidimensi dilakukan dengan menerapkan Lemma Ito.

Definisi 1 (Lemma Ito):

Misalkan diberikan sebuah fungsi $G$ dari $X_{t}$ dan $t$ atau ditulis $G\left(X_{t}, t\right)$ yang merupakan fungsi kontinu dan diferensiabel. $X_{t}$ adalah proses Itô yang didefinisikan sebagai berikut:

$$
d X_{t}=a\left(X_{t}, t\right) d t+b\left(X_{t}, t\right) d W_{t}
$$

dengan $W_{t}$ merupakan proses Gerak Brown standar, maka $G\left(X_{t}, t\right)$ mempunyai bentuk diferensial stokastik sebagai berikut:

$$
\begin{gathered}
d G\left(X_{t}, t\right)=\left(\frac{\partial G}{\partial t}+a\left(X_{t}, t\right) \frac{\partial G}{\partial X_{t}}+\right. \\
\left.\frac{1}{2} b\left(X_{t}, t\right)^{2} \frac{\partial^{2} G}{\partial X_{t}^{2}}\right) d t+b\left(X_{t}, t\right) \frac{\partial G}{\partial X_{t}} d W_{t}
\end{gathered}
$$

Dari penerapan Lemma di atas akan dihasilkan solusi sebagai berikut :

$$
\begin{aligned}
S_{t}^{i}=S_{t-1}^{i} \exp & {\left[\left(\mu_{i}-\frac{1}{2} \sum_{j=1}^{3}\left(\sigma_{i j}\right)^{2}\right) d t\right.} \\
& \left.+\sum_{j=1}^{3} \sigma_{i j} d W_{j}\right] .
\end{aligned}
$$

Solusi di atas yang kemudian disebut model GBG Multidimensi. Model ini merepresentasikan bahwa harga saham di periode mendatang selalu bernilai positif dan return saham diasumikan berdistribusi normal dan bersifat independen.

Konsep dasar yang dinyatakan dalam portofolio optimal adalah bagaimana mengalokasikan sejumlah dana tertentu pada berbagai jenis investasi yang akan menghasilkan keuntungan yang optimal. Terdapat beberapa teknik yang dapat dilakukan untuk membentuk portofolio optimal. Pada penelitian ini, pembentukan portofolio optimal dilakukan dengan Teori Portofolio Markowitz. Hal tersebut didasarkan pada parameter yang dirumuskan dalam pembentukan portofolio optimal ialah parameter serupa yang terdapat dalam solusi PDS portofolio saham.

Pada pembentukan portofolio optimal dengan model Markowitz, portofolio optimal yang terbentuk merupakan pilihan dari bebagai sekuritas dari portofolio efisien. Portofolio efisien ialah portofolio yang memberikan pengembalian maksimal pada tingkat risiko tertentu atau memiliki tingkat risiko minimal pada tingkat pengembalian tertentu. Kumpulan portofolio efisien Markowitz terletak pada garis batas (efficient frontier) serangkaian portofolio efisien.

Alokasi dana yang diberikan pada masingmasing saham akan berpengaruh terhadap tingkat pengembalian saham dan tingkat risiko yang dihasilkan. Investor dapat melakukan sejumlah kombinasi alokasi dana pada masingmasing saham untuk memperoleh sejumlah portofolio yang diinginkan. Berdasarkan sejumlah portofolio yang telah dibentuk, dapat ditentukan portofolio optimal dengan cara optimasi sebagai berikut (Husnan, [3]):

$$
\text { Minimumkan: } \sum w_{i}^{2} \sigma_{i}^{2}+\sum \sum w_{i} w_{j} \sigma_{i j}
$$

Dengan batasan

$$
\begin{array}{ll}
\text { 1. } & \sum w_{i}=1 \\
\text { 2. } & \sum w_{i} \mu_{i}=E\left(R_{p}\right) \\
\text { 3. } & w_{i} \geq 0, \quad i=1,2,3
\end{array}
$$

\section{METODE PENELITIAN}

Data yang digunakan dalam penelitian ini adalah data harga penutupan dari tiga buah saham yaitu Bank Central Asia Tbk (BBCA), 
PT Indofood CBP Sukses Makmur Tbk (ICBP), dan PT Indocement Tunggal Prakarsa Tbk (INTP). pada periode Januari 2013 - Desember 2014 yang kemudian akan dibentuk sebagai suatu portofolio. Jenis data ini adalah data sekunder yang diperoleh melalui alamat web http://finance.yahoo.com.

Langkah-langkah analisis data dalam penelitian ini adalah :

1. Mengumpulkan data harga penutupan saham dari saham BBCA, ICBP, dan INTP.

2. Membentuk model pergerakan harga tiga saham yang dirumuskan dalam suatu Persamaan Diferensial Stokastik 3 Dimensi dan menghitung solusi eksak dari model yang telah terbentuk.

3. Melakukan uji normalitas dan uji independensi terhadap data return dari masing-masing saham. Uji normalitas dilakukan dengan Uji Kolmogorov Smirnov dan uji independensi melalui Run Test.

4. Melakukan simulasi harga saham yang bergerak dengan model Gerak Brown Geometri Multidimensi.

5. Membentuk portofolio optimal Markowitz dari ketiga saham.

\section{HASIL DAN PEMBAHASAN}

Berikut proses dan hasil implementasi yang diperoleh pada penelitian ini:

\section{A. Model Pergerakan Harga Tiga Saham}

Misalkan harga saham Bank Central Asia Tbk (BBCA), PT Indofood CBP Sukses Makmur Tbk (ICBP), dan PT Indocement Tunggal Prakarsa Tbk (INTP) secara berturutturut dinyatakan sebagai $S_{t}^{1}, S_{t}^{2}$, dan $S_{t}^{3}$. Ekspektasi tingkat pengembalian saham per satuan waktu pada masing-masing saham di atas disimbolkan dengan $\mu_{1}, \mu_{2}$, dan $\mu_{3}$, sedangkan volatilitas saham yang direpresentasikan sebagai deviasi standar saham secara berturut-turut disimbolkan dengan $\sigma_{1}, \sigma_{2}$, dan $\sigma_{3}$.

Model pergerakan tiga saham yang terbentuk adalah sebagai berikut:

$$
d S_{t}^{i}=S_{t}^{i}\left(\mu_{i} d t+\sum_{j=1}^{3} \sigma_{i j} d W_{j}\right)
$$

untuk $i=1,2,3$.

Dengan menerapkan Lemma Ito diperoleh solusi berikut :

$$
\begin{aligned}
S_{t}^{i}=S_{t-1}^{i} \exp & {\left[\left(\mu_{i}-\frac{1}{2} \sum_{j=1}^{3}\left(\sigma_{i j}\right)^{2}\right) d t\right.} \\
& \left.+\sum_{j=1}^{3} \sigma_{i j} d W_{j}\right]
\end{aligned}
$$

untuk $i=1,2,3$. Solusi tersebut disebut model GBG 3 Dimensi dan merepresentasikan harga saham di masa mendatang selalu bernilai positif.

Pada model PDS Tiga Dimensi di atas diketahui bahwa terdapat tiga parameter yang diperhitungkan. Tiga parameter tersebut ialah expected return saham, varians atau deviasi standar saham, dan korelasi antar saham.

\section{B. Uji Asumsi Model Gerak Brown Geometri}

Harga saham diasumsikan mengikuti model Gerak Brown Geometri 3 Dimensi dengan return saham merupakan suatu Gerak Brown. Untuk menguji asumsi tersebut, maka akan dilakukan uji normalitas dan uji independensi pada masing-masing return saham. Uji normalitas yang digunakan dalam penelitian ini berupa Uji Kolmogorov Smirnov dan uji independensi berupa Run Test.

a. Uji Kolmogorov Smirnov

Adapun hipotesis pada uji ini yaitu:

$H_{0}$ : return saham berditribusi normal

$H_{1}$ : return saham tidak berditribusi normal

Berikut ditampilkan hasil uji Kolmogorov Smirnov dari return saham: 
Tabel 1. Uji Kolmogorov Smirnov dari Masing-masing Return Saham

\begin{tabular}{|c|c|c|c|}
\hline No & Saham & Z-Stat & P-Value \\
\hline 1 & BBCA & 2,221 & 0,001 \\
\hline 2 & ICBP & 2,491 & 0,005 \\
\hline 3 & INTP & 2,003 & 0,001 \\
\hline
\end{tabular}

Karena semua nilai signfikansi ( $p$-value) lebih kecil dari taraf kepercayaan ( $\alpha=5 \%)$, yang mengindikasikan tolak $H_{0}$, yang artinya data berdistribusi tidak normal, sehingga dilakukan transformasi data.

Tabel 2. Uji Kolmogorov Smirnov dari Transformasi Masing-masing Return Saham

\begin{tabular}{|c|c|c|c|}
\hline No & Saham & Z-Stat & P-Value \\
\hline 1 & BBCA & 1,332 & 0,258 \\
\hline 2 & ICBP & 0,999 & 0,271 \\
\hline 3 & INTP & 1,002 & 0,268 \\
\hline
\end{tabular}

Pada Tabel 2 dapat dilihat bahwa untuk semua nilai signifikasnsi ( $p$-value) lebih besar dari taraf kepercayaan ( $\alpha=5 \%)$, yang mengindikasikan terima $H_{0}$, yang artinya data (return saham) berdistribusi normal.

b. Uji Indepedensi

Berdasarkan uji Kolmogorov Smirnov di atas, diketahui bahwa asumsi kenormalan data dipenuhi oleh data return saham yang telah ditransformasi. Oleh karena itu, uji independensi akan dilakukan terhadap data return saham yang telah ditransformasi. Adapun hipotesis dari uji ini yaitu:

$H_{0}$ : return saham acak (random)

$H_{1}$ : return saham tidak acak
Hasil Run Test untuk masing-masing return saham dapat dilihat pada tabel berikut:

Tabel 3. Uji Run Test dari Masingmasing Return Saham

\begin{tabular}{|c|c|c|c|}
\hline No & Saham & Z-stat & P-Value \\
\hline 1 & BBCA & 0,463 & 0,643 \\
\hline 2 & ICBP & 1,395 & 0,163 \\
\hline 3 & INTP & 1,363 & 0,173 \\
\hline
\end{tabular}

Pada Tabel 3 dapat dilihat bahwa untuk semua nilai signifikansi ( $p$-value) lebih besar dari taraf kepercayaan $(\alpha=5 \%)$, yang mengindikasikan terima $H_{0}$, yang artinya data masing-masing return saham cukup acak (random) sehingga tidak terdapat masalah autokorelasi pada data yang diuji.

\section{Simulasi Saham dengan Model Gerak Brown Geometri Multidimensi}

Model Gerak Brown Geometri 3 Dimensi yang diperoleh pada pembentukan model pergerakan tiga saham merupakan nilai estimasi dari pergerakan harga saham pada pasar saham multidimensi. Selanjutnya model tersebut akan digunakan sebagai rumusan untuk melihat estimasi (pendekatan) harga saham pada periode mendatang melalui simulasi pergerakan harga saham.

Hasil simulasi saham dengan model Gerak Brown Geometri Multidimensi ditampilkan pada gambar 1.

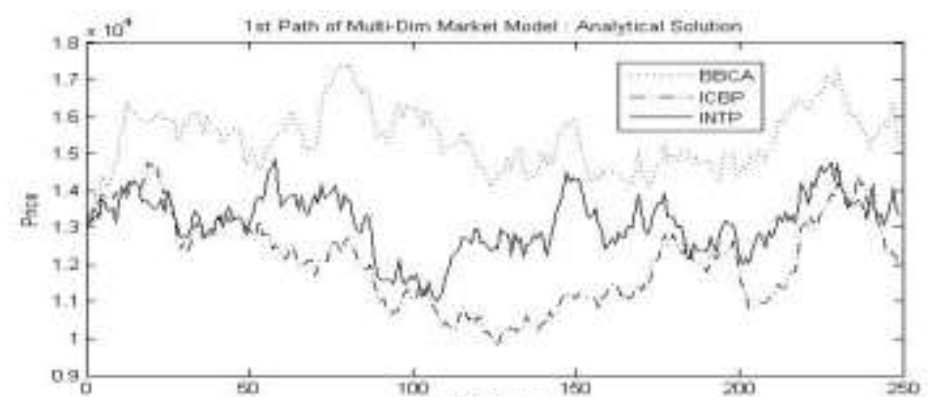

Gambar 1. Simulasi Saham dengan Model Gerak Brown Geometri Multidimensi untuk 249 
Estimasi (pendugaan) pergerakan harga saham pada periode mendatang dari saham Bank Central Asia Tbk (BBCA), PT Indofood CBP Sukses Makmur Tbk (ICBP), dan PT Indocement Tunggal Prakarsa Tbk (INTP) yang diasumsikan mengikuti model Gerak Brown Geometri Tiga Dimensi dapat dilihat pada Gambar 1. Hasil estimasi (pendugaan) harga saham pada periode mendatang dari saham BBCA ialah 15.254, saham ICBP ialah 13.365, dan INTP ialah 12.304. Pada plot hasil simulasi dengan model GBG Tiga Dimensi tersebut ditunjukkan pula pendugaan pergerakan ketiga harga saham dengan periode pengamatan selama 249 hari.

\section{Menentukan Portofolio Optimal}

Terdapat tiga parameter yang dilibatkan dalam pemodelan pergerakan ketiga saham yang mengikuti model Gerak Brown Geometri Multidimensi yaitu expected return saham, volatilitas saham, dan koefisien korelasi saham. Berdasarkan hal tersebut peneliti akan menggunakan model Markowitz sebagai model dalam analisis pembentukan portofolio optimal, karena pada model Markowitz, menggunakan pengukuran statistika dasar dalam pembentukan portofolio optimalnya.

Pada penelitian ini, short sales tidak diperkenankan dilakukan oleh investor. Short sales berarti menjual saham yang tidak dimiliki. Karena short sales tidak diperkenankan, maka investor hanya bisa menginvestasikan dana maksimum sebesar $100 \%$ pada suatu sekuritas dan minimum sebesar $0 \%$.

Berikut hasil pengolahan data dan pembentukan portofolio optimal Markowitz:

a. Expected Return Saham

Expected return saham merupakan nilai yang menggambarkan bagaimana keadaan harga saham yang dapat diperoleh dengan menjumlahkan seluruh return saham kemudian dibagi dengan periode penelitian. Hasil perhitungan expected return saham disajikan dalam Tabel 4.
Tabel 4. Expected Return Masing-masing Saham

\begin{tabular}{|c|c|c|}
\hline No & Saham & Expected Return \\
\hline 1 & BBCA & 0,0007043 \\
\hline 2 & ICBP & 0,0009484 \\
\hline 3 & INTP & 0,0002545 \\
\hline
\end{tabular}

b. Deviasi Standar Saham

Deviasi standar saham merepresentasikan volatilitas saham. Volatilitas saham merupakan besarnya jarak antara fluktuasi atau naik turunnya harga saham. Hasil perhitungan standar deviasi masing masing saham dapat dilihat pada Tabel 5 .

Tabel 5. Standar Deviasi Masing-masing Saham

\begin{tabular}{|c|c|c|}
\hline No & Saham & Deviasi Standar \\
\hline 1 & BBCA & 0,0175 \\
\hline 2 & ICBP & 0,0206 \\
\hline 3 & INTP & 0,0223 \\
\hline
\end{tabular}

c. Matriks Korelasi Saham

Unsur-unsur matriks ini berupa koefisien korelasi dari sekumpulan saham. Diagonalnya berupa angka 1, sedangkan unsur lainnya berupa koefisien korelasi antar saham. Matriks korelasi antar saham diasajikan pada tabel 6 .

Tabel 6. Koefisien Korelasi Antar Saham

\begin{tabular}{|c|c|c|c|c|}
\hline \multirow{2}{*}{ No } & \multirow{2}{*}{ Saham } & \multicolumn{3}{|c|}{ Koefisien Korelasi } \\
\cline { 3 - 5 } & BBCA & ICBP & INTP \\
\hline 1 & BBCA & 1 & 0,3793 & 0,4409 \\
\hline 2 & ICBP & 0,3793 & 1 & 0,3891 \\
\hline 3 & INTP & 0,4409 & 0,3891 & 1 \\
\hline
\end{tabular}

Tabel 6 menunjukkan hasil perhitungan koefisien korelasi antar saham secara matematika dan Gambar 1 yang memberikan gambaran secara grafik terkait koefisien korelasi melalui arah pergerakan harga saham pada periode mendatang, diketahui bahwa tiga hubungan (korelasi) dari saham-saham tersebut memiliki korelasi yang positif, artinya pergerakan harga saham- 
sahamnya adalah searah yaitu ketika harga saham yang satu naik, maka harga saham lainnya juga cenderung bergerak naik, begitu juga yang terjadi ketika harga saham bergerak turun. Dari ketiga korelasi yang terjadi, korelasi antara saham BBCA dan INTP memiliki koefisien korelasi yang paling besar.

d. Komposisi Dana Saham

Berdasarkan konsep dasar Teori Portofolio Markowitz, peneliti akan memasukkan nilai yang berbeda-beda untuk alokasi dana pada masing-masing saham, sehingga akan diperoleh sejumlah portofolio yang diinginkan. Berikut hail komposisi dana saham dari 10 portoflio yang dibentuk:

Tabel 7. Komposisi Dana Masing-masing Saham

\begin{tabular}{|c|c|c|c|}
\hline \multirow{2}{*}{ No. } & \multicolumn{3}{|c|}{ Komposisi (\%) } \\
\cline { 2 - 4 } & BBCA & ICBP & INTP \\
\hline 1 & 58,53 & 37,91 & 3,56 \\
\hline 2 & 16,80 & 57,56 & 25,64 \\
\hline 3 & 25,91 & 39,36 & 34,73 \\
\hline 4 & 39,38 & 59,82 & 0,80 \\
\hline 5 & 73,88 & 14,61 & 11,51 \\
\hline 6 & 55,60 & 29,61 & 14,79 \\
\hline 7 & 28,70 & 58,81 & 12,49 \\
\hline 8 & 1,20 & 59,57 & 39,23 \\
\hline 9 & 54,62 & 27,28 & 18,10 \\
\hline 10 & 28,93 & 58,14 & 12,93 \\
\hline
\end{tabular}

e. Expected Return Portofolio dan Risiko Portofolio

Berdasarkan komposisi dana dari ketiga saham pada Tabel 7, maka diperoleh besarnya tingkat pengembalian portofolio dan risiko portofolio sebagai berikut:

Tabel 8. Expected Return Portofolio dan Risiko Portofolio

\begin{tabular}{|c|c|c|}
\hline No. Port & $\begin{array}{c}\text { Tingkat } \\
\text { Pengembalian } \\
\text { Port }\end{array}$ & $\begin{array}{c}\text { Risiko } \\
\text { Port }\end{array}$ \\
\hline 1 & 0,00078 & 0,0155 \\
\hline 2 & 0,00072 & 0,0166 \\
\hline 3 & 0,00064 & 0,0159 \\
\hline 4 & 0,00084 & 0,0163 \\
\hline 5 & 0,00068 & 0,0157 \\
\hline 6 & 0,00071 & 0,0152 \\
\hline 7 & 0,00079 & 0,0162 \\
\hline 8 & 0,00067 & 0,0177 \\
\hline 9 & 0,00068 & 0,0152 \\
\hline 10 & 0,00078 & 0,0162 \\
\hline
\end{tabular}

Selanjutnya dengan menerapkan konsep dasar Teori Portofolio Markowitz, akan diperoleh portofolio optimal dari 10 portofolio yang telah terbentuk. Sepuluh portofolio yang terbentuk akan ditampilkan dalam satu plot dengan efficient frontier dari model Markowitz pada Gambar 2.

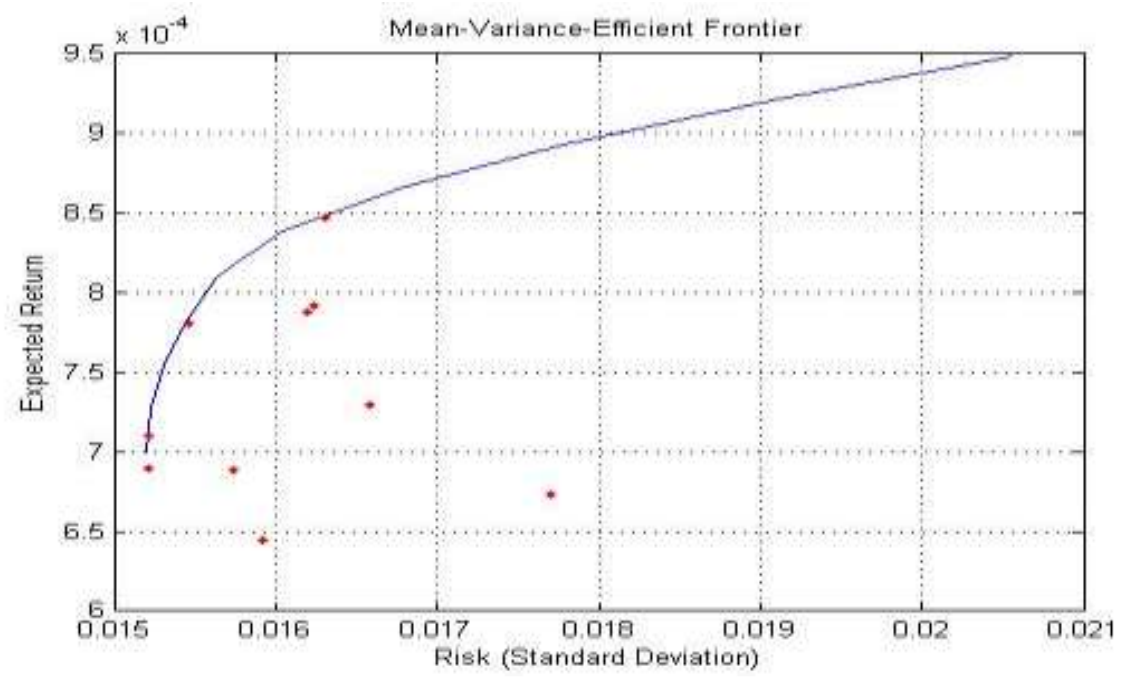

Gambar 2. Mean-Variance Efficient Frontier for Three Asset 
Plot Mean - Variance Efficient Frontier for Three Asset (Gambar 2) menunjukkan portofolio yang telah terbentuk dalam satu plot dengan efficient frontier Markowitz. Garis biru pada Gambar 2 tersebut menunjukkan garis batas dari portofolio yang efisien (efficient frontier), sedangkan titik-titik merah menunjukkan portofolio-portofolio yang terbentuk. Berdasarkan plot yang ditunjukkan Gambar 2, dapat dilihat bahwa dari 10 portofolio yang terbentuk, terdapat tiga portofolio yang dikategorikan sebagai portofolio yang efisien.

Dari ketiga portofolio efisien tersebut terpilih satu portofolio yang dikategorikan sebagai portofolio optimal dengan cara optimasi pada persamaan (2.30), yaitu portofolio yang memiliki tingkat pengembalian portofolio sebesar 0,00084 , risiko portofolio sebesar 0,0163 dan memiliki komposisi dana saham BBCA, ICBP, INTP secara berturutturut sebesar 39,38\%; 59,82\%; dan 0,80\%.

Berdasarkan hasil perhitungan portofolio optimal di atas, diketahui bahwa porporsi dana yang paling besar diperoleh oleh saham ICBP. Hal ini sebanding dengan expected return yang dihasilkan oleh saham ICBP (Tabel 4). Saham ICBP memberikan expected return yang paling tinggi dibandingkan dua saham lainnya. Sedangkan proporsi dana paling kecil diberikan untuk saham INTP, karena saham INTP memberikan expected return yang paling kecil dan memiliki deviasi standar (volatilitas) yang paling tinggi. Volatilitas tinggi adalah harga sahan yang naik tinggi dengan cepat lalu tiba-tiba turun, sehingga risiko yang dimiliki cukup besar.

\section{KESIMPULAN DAN SARAN}

Berdasarkan penelitian yang dilakukan terhadap portofolio dari tiga buah saham yang bergerak mengikuti model Gerak Brown Geometri Tiga Dimensi, diperoleh kesimpulan bahwa:
1. Simulasi harga saham yang bergerak dengan model Gerak Brown Geometri Tiga Dimensi merepresentasikan bahwa pergerakan harga saham pada periode mendatang dipengaruhi oleh tiga parameter, yaitu tingkat pengembalian saham, risiko saham individu, dan korelasi yang terjadi antar masing-masing saham.

2. Teknik analisis yang digunakan untuk menentukan portofolio optimal pada saham yang bergerak dengan model Gerak Brown Geometri Tiga Dimensi ialah Teori Portofolio Markowitz. Portofolio optimal yang terbentuk ialah portofolio dengan alokasi dana 39,38\% untuk saham BBCA, $59,82 \%$ untuk saham ICBP, dan $0,80 \%$ untuk saham INTP.

Pada penelitian ini objek atau model yang digunakan untuk melakukan simulasi estimasi harga pada pasar saham multidimensi ialah model Gerak Brown Geometri. Model ini mengamati return dan deviasi standar (volatilitas) pada saham yang dianggap konstan. Pada penelitian selanjutnya, dapat dijadikan pertimbangan untuk melakukan simulasi estimasi harga pada pasar saham multidimensi dengan objek atau model lain yaitu model Constant Elasticity of Variance (CEV). Model ini mengamati volatilitas yang bersifat stokastik atau volatitilitas tidak dianggap konstan.

\section{DAFTAR PUSTAKA}

[1] Black F, Scholes M. 1973. The Pricing of Options and Corporate Liabillities. The Journal of Political Economy, Vol. 81, No. 3, 637-654.

[2] Fama, Eugene. 1970. Efficient Capital Markets - A review of theory and emperical work. The Journal of Finance, Vol .25, No. 2, 338-417.

[3] Husnan, Suad. 2003. Dasar - Dasar Teori Portofolio dan Analisis Sekuritas. Yogyakarta: Unit Penerbit dan Percetakan AMP YKPN.

[4] Kloeden P.E, Platen E. 1992. Numerical Solution of Stochastic Differential 
Equation. New York: Springer-Verlag Berlin Heidelberg.

[5] Nizaruddin. 2011. Penerapan Kalkulus Stokastik Pada Model Opsi. Jurnal Program Studi Pendidikan Matematika, Vol. 2, No. 1, 1-14.

[6] Noorbaity, Aisiyah S. 2012. Aproksimasi PDS Harga Saham Menggunakan Metode Numerik PDS Implisit . Jurnal Ekonomi dan Bisnis, Vol. 11, No. 1, 4952.

[7] Pradhitya, K.A. 2012. Perhitungan Harga Opsi Eropa dengan Metode Gerak Brown Geometrik.

http://respository.uksw.edu/bitsream/123 456789/2359/3/T1_662008002_Lampira n.pdf. Diakses tanggal 7 Desember 2014 